\title{
Effect of Starter Culture on the Fatty Acid and Amino Acid Profile of Fermented Parkia biglobosa Seeds
}

\author{
*ATERE Ayowole V., OYETAYO Victor O. and AKINYOSOYE Felix A. \\ Depatrment of Microbiology, Federal University of Technology, Akure, P.M.B 704 Akure, Nigeria. \\ *e-mail: victor_efosa001@yahoo.com, ovonew67@gmail.com, felixkinsola@yahoo.com
}

\section{Key words: Fatty acids, Amino acids, Parkia biglobosa, Iru, Fermentation}

\begin{abstract}
Iru, a condiment used for seasoning soup is often obtained from the fermentation of Parkia biglobosa seeds. The present study therefore investigates the effect of different starter culture on the amino and fatty acid profile of Parkia biglobosa seed fermented to produce iru. Starter culture of Lactobacillus plantarum, Bacillus subtilis and Leuconostoc mesenteroides were used to ferment Parkia biglobosa seeds. The bacterial load increased from $0.00 \log _{10} \mathrm{cfu} / \mathrm{g}$ in boiled raw sample to $8.67 \log _{10} \mathrm{cfu} / \mathrm{g}$ in naturally fermented sample. Fermentation significantly $(\mathrm{P}<0.05)$ increased the quantity of the amino acids in fermented samples. Aspartic acid $(25.85 \mathrm{~g} / 100 \mathrm{~g})$ and linoleic acid $(42.99 \%)$ were the highest amino and fatty acids respectively in the fermented samples. The result from this study reveals that fermentation significantly increase the amino and fatty acid profile of Parkia biglobosa fermented to produce iru, a Nigerian condiment.
\end{abstract}

\section{Introduction}

Fermented food form an integral part of the African diet. These foods are generally fermented as a method of preservation, to increase the safety and also to produce a lot of varieties [1]. Fermentation has been reported to also increase the nutritional value of the fermented product, increase the digestibility and also degrade hazardous components in the raw materials. In the African countries, rural dwellers who cannot afford animal products such as meat or dairy, which supplies the needed protein requirement in diets rely on fermented legumes [2, 3, 4]. Legumes has been providing the needed daily requirement of protein for these rural population because of the reduced cost of production, less difficult to process and the high energy value supplied [5].

Among the leguminous plants used by African population, Parkia biglobosa seeds had gained popularity. It is a perennial tree belonging to the family Leguminoseae and sub-family Mimosadeae. The seeds of Parkia biglobosa are fermented into 'iru' which is an indigenous fermented food condiment among the Yoruba people of Western Nigeria in West Africa [6]. The production process is usually on a small scale house-hold basis under varying condition [7]. The production of iru involve soaking the Parkia biglobosa seeds for about 30 minutes before cooking [1]. The cooked seeds were dehalled and cotyledon washed and recook, the cotyledon were then packed in containers for fermentation to take place $[1,2,4,6,7]$. However, the optimum condition for the fermentation procedure has been documented to be $35{ }^{\circ} \mathrm{C}$ for 36 hours [8].

The production of 'iru' is left to chance inoculation. This often cause variation in the product. The presence of varying array of bacteria may also be a factor that leads to contaminating organisms producing secondary metabolites which often lead to inconsistency in the final product. Elemo et al. [9] had earlier reported that the seeds of Parkia biglobosa could be a good source of amino and fatty acids.

Both fatty acids and amino acids plays multiple role in living cells. They form part of the major component of the cell. The fatty acid containing lipids form the back bone of all cell membrane. Fatty acids are important energy sources and can be stored in unlimited quality in the body [10, 11]. Therefore, to get a product that is nutritionally stable, consideration should be given to the use of starter culture where known bacteria are used to ferment the seeds. The present study was therefore 
designed to investigate effect of starter culture on the amino acid and fatty acid profile of Parkia biglobosa seeds fermented to produce 'iru' a Nigerian condiment.

\section{Methodology}

\section{Source of materials}

The raw seeds of African locust beans (Parkia biglobosa) was gotten from Oja Oba, a local market in Omuo-Ekiti, Ekiti State of Nigeria.

\section{Production of 'iru'}

Iru was produced using the method described by [1]. The dried seeds of Parkia biglobosa were soaked for 30 mins and later cooked under pressure for $2 \mathrm{~h}$. The cooked seeds were dehulled and the cotyledons were washed with water. The well washed cotyledons were re-cooked under pressure for $1 \mathrm{~h}$. The excess water was drained and poured into fermenters, where starter cultures were introduced. The inoculated seed were fermented for $72 \mathrm{~h}$.

\section{Microbiological analysis}

A standard microbiological procedure was used [1]. The pure culture of the isolates (Starter culture) were activated in $13 \%$ buffer peptone water. The turbidity was matched with the 0.5 MaCfaland standard and diluted to give $10^{4}$ cells/ $\mathrm{ml}$. Isolates of Lactobacillus plantarum, Leuconostoc mesenteroides and Bacillus subtilis were used as starter culture. The bacteria load of the samples were determined using the serial dilution and pour plate method using nutrient agar. The plates were allowed to gel and inverted. The inverted plates were incubated in the incubator for $24 \mathrm{~h}$. the colonies were counted using a colony counter. The number of colonies were enumerated as colony forming unit per gram $(\mathrm{CFU} / \mathrm{g})$.

\section{Determination of amino acid Profile}

Modified method of [12] was used in the extraction of the sample for the amino acid analysis. About 5 grams of the sample was weighed into the $250 \mathrm{~mL}$ conical flask. The sample was defatted by extracting the fat content of the sample with $30 \mathrm{~mL}$ of the petroleum spirit with soxhlet extractor that was equipped with thimble. Then the samples were hydrolysed three times for complete hydrolysis to be achieved. The concentration of the amino acid in the samples were determined using the Technicon Sequential Multi-sample amino Acid Analyzer (TMS) (Model 120A, Japan). The dry samples were defatted and hydrolyzed in $6 \mathrm{M} \mathrm{HCL}$ for $24 \mathrm{~h}$ at $110^{\circ} \mathrm{C}$. After cooling, the hydrolysate was evaporated in a vacuum evaporator, the dry residue was dissolved in a buffer and analyzed with Amino acid analyzer. The concentrations of the amino acids (in $\mathrm{g} / 100 \mathrm{~g}$ protein) were calculated from external standards for the different amino acids.

\section{Determination of the fatty acids}

The samples were extracted using Petroleum ether. Fifty (50) $\mathrm{mg}$ of the extracted fat content of the sample was saponified (esterified) for five (5) minutes at $95^{\circ} \mathrm{C}$ with $3.4 \mathrm{ml}$ of the $0.5 \mathrm{M} \mathrm{KOH}$ in dry methanol. The mixture was neutralized by using $0.7 \mathrm{M} \mathrm{HCl}$. Three milliliter $(3 \mathrm{ml})$ of $14 \%$ boron triflouride in methanol was added. The mixture was heated for 5 minutes at the temperature of $90{ }^{\circ} \mathrm{C}$ to achieve complete methylation process. The Fatty Acid methyl ester were thrice extracted from the mixture with redistilled $\mathrm{n}$-hexane. The content was concentrated to $1 \mathrm{ml}$ for gas chromatography analysis and $1 \mu \mathrm{l}$ was injected into port of gas chromatography. (GC: HP 6890 powered with HP ChemStation Rev. A09.01 [1206] Software, Injection Temperature: Split Injection, Split Ratio: 20:1, Carrier: Gas Notrogen, Inlet Temperature: $250{ }^{\circ} \mathrm{C}$, Colomn Type: HP INNOWax, Colomn Dimensions: $30 \mathrm{~m}$ x $0.25 \mathrm{~mm}$ x $0.25 \mu \mathrm{m}$, Detector: FID, Detector Temperature: $320{ }^{\circ} \mathrm{C}$, Hydrogen Pressure: 22psi, Compressed Air: 35psi) 


\section{Statistical Analysis}

The data collected were subjected to analysis of variance (ANOVA) and means separated with Duncan's Multiple Range Test (DMRT) using Statistical Package for Social Sciences (SPSS version $16.02010)$.

\section{Results}

The microbial load of the fermented Parkia biglobosa seeds fermented to produced 'iru' after $72 \mathrm{~h}$ of fermentation was $8.67 \pm 0.16 \log _{10} \mathrm{cfu} / \mathrm{g}$ in samples fermented naturally and $8.65 \pm 0.07 \log _{10} \mathrm{cfu} / \mathrm{g}$ in samples fermented with culture of Bacillus subtilis, the cooked unfermented had no growth, as presented in Figure 1.

The amino acid profile of the raw and fermented seeds of Parkia biglobosa is presented in Table 1. For the total essential amino acids, samples fermented with Leuconostoc mesenteroides. had $32.10 \pm 0.20 \mathrm{~g} / 100 \mathrm{~g}$ while the sample naturally fermented had $32.14 \pm 0.07 \mathrm{~g} / 100 \mathrm{~g}$. The conditionally essential amino acids was $18.57 \pm 0.54 \mathrm{~g} / 100 \mathrm{~g}$ in the raw seeds and $18.48 \pm 0.26 \mathrm{~g} / 100 \mathrm{~g}$ in samples fermented with Bacillus subtilis while samples fermented with Lactobacillus plantarum had $17.50 \pm 0.08 \mathrm{~g} / 100 \mathrm{~g}$ which is the least in the series. In the non-essential amino acids, samples fermented with Bacillus subtilis had the highest with a value of $50.12 \pm 0.07 \mathrm{~g} / 100 \mathrm{~g}$ and the raw seeds had the least value of $35.57 \pm 1.46 \mathrm{~g} / 100 \mathrm{~g}$.

The highest amino acid recorded was aspartic acid with a value of $25.85 \pm 0.03 \mathrm{~g} / 100 \mathrm{~g}$ in samples fermented with Bacillus subtilis, $23.54 \pm 0.35 \mathrm{~g} / 100 \mathrm{~g}$ in sample fermented with Lactobacillus plantarum and $11.06 \pm 0.88 \mathrm{~g} / 100 \mathrm{~g}$ in the raw seeds. Glutamic acid was found highest in sample fermented naturally with a value of $16.07 \pm 0.02 \mathrm{~g} / 100 \mathrm{~g}$ while it was $15.18 \pm 0.47 \mathrm{~g} / 100 \mathrm{~g}$ in the raw seeds. Glycine was highest in sample fermented in with Bacillus subtilis with a value of $4.81 \pm 0.01 \mathrm{~g} / 100 \mathrm{~g}$ and $3.88 \pm 0.01 \mathrm{~g} / 100 \mathrm{~g}$ in the sample fermented with Lactobacillus plantarum. Lysine was found highest in sample fermented with Leuconostoc mesenteroides with a value of $5.86 \pm 0.03 \mathrm{~g} / 100 \mathrm{~g}$. Threonine was highest in sample fermented with Bacillus subtilis with a value of $3.85 \pm 0.02 \mathrm{~g} / 100 \mathrm{~g}$.

Table 2 presents the fatty acid profile of raw and fermented Parkia biglobosa seeds. Caprylic acid and capric acid were not detected in the raw and fermented samples. Lauric acid was not detected in the raw seeds but present in the fermented samples.

The total saturated fatty acid was highest in the raw seeds with a value of $37.799 \pm 0.03 \%$ and least in the sample fermented with Lactobacillus plantarum with a value of $31.765 \pm 0.13 \%$. The highest palmitic acid was found in the raw seeds with a value of $19.400 \pm 0.01 \%$ and least in sample fermented with Lactobacillus plantarum with a value of $14.221 \pm 0.06 \%$. For the monounsaturated fatty acids the samples fermented with Lactobacillus plantarum had the highest value of $25.365 \pm 0.05 \%$ while the raw seed had $21.033 \pm 0.03 \%$.

Linoleic acid was found to be the highest fatty acid. The highest value of linoleic acid was found in the sample fermented with Lactobacillus plantarum (42.99 $\pm 0.06 \%$ ). The raw seeds had $36.074 \pm 0.01$ $\%$. Erucic acid was highest in the raw seeds $(3.39 \pm 0.01 \%)$ and reduced after fermentation to a value of $0.226 \%$ in the naturally fermented, 0.423 in the samples fermented with Bacillus subtilis, $0.175 \%$ in sample fermented with Leuconostoc sp and $0.195 \%$ in samples fermented with Lactobacillus plantarum. The total polyunsaturated fatty acids was highest in sample fermented with Lactobacillus plantarum with a value of $42.873 \%$ followed by sample fermented naturally $(41.22 \%)$, sample fermented with Bacillus subtilis had $41.089 \%$ and the least value was recorded in the raw seed $(40.5 \%)$. 
10

9

8

7

6

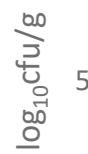

4

3

2

1

0

$\begin{array}{ccccc}\text { Unfermented } & \begin{array}{c}\text { Fermented with } \\ \text { Lactobacillus } \\ \text { plantarum }\end{array} & \begin{array}{c}\text { Fermented with } \\ \text { Leuconostoc sp }\end{array} & \begin{array}{c}\text { Fermented with } \\ \text { Bacillus subtilis }\end{array} & \begin{array}{c}\text { Fermented } \\ \text { Naturally }\end{array} \\ & & & \end{array}$

Figure 1. Bacterial load of unfermented and fermented Parkia biglobosa seeds 
Table 1. Amino acid profile of raw and fermented Parkia biglobosa seeds

\begin{tabular}{|c|c|c|c|c|c|c|}
\hline $\mathrm{s} / \mathrm{n}$ & Amino acids & Raw seeds & $\begin{array}{c}\text { Natural } \\
\text { fermentation }\end{array}$ & $\begin{array}{c}\text { Fermented } \\
\text { with Bacillus } \\
\text { subtilis }\end{array}$ & $\begin{array}{l}\text { Fermented with } \\
\text { Leuconostoc } \\
\text { mesenteroides }\end{array}$ & $\begin{array}{l}\text { Fermented } \\
\text { with } \\
\text { Lactobacillus } \\
\text { plantarum }\end{array}$ \\
\hline \multicolumn{7}{|c|}{ Essential amino acids } \\
\hline 1 & Lysine & $3.30 \pm 0.18^{\mathrm{a}}$ & $5.84 \pm 0.01^{\mathrm{c}}$ & $5.62 \pm 0.01^{\mathrm{bc}}$ & $5.86 \pm 0.03^{\mathrm{c}}$ & $5.51 \pm 0.01^{\mathrm{b}}$ \\
\hline 2 & Threonine & $3.85 \pm 0.02^{\mathrm{d}}$ & $3.00 \pm 0.01^{\mathrm{b}}$ & $3.85 \pm 0.02^{\mathrm{d}}$ & $3.12 \pm 0.01^{\mathrm{c}}$ & $2.87 \pm 0.01^{\mathrm{a}}$ \\
\hline 3 & Valine & $3.26 \pm 0.13^{\mathrm{a}}$ & $5.04 \pm 0.01^{\mathrm{c}}$ & $4.86 \pm 0.01^{\mathrm{bc}}$ & $4.77 \pm 0.03^{b}$ & $4.67 \pm 0.01^{\mathrm{b}}$ \\
\hline 4 & Methionine & $1.15 \pm 0.03^{b}$ & $1.21 \pm 0.01^{\mathrm{c}}$ & $1.13 \pm 0.01^{b}$ & $1.22 \pm 0.01^{\mathrm{c}}$ & $0.93 \pm 0.01^{\mathrm{a}}$ \\
\hline 5 & Isoleucine & $3.82 \pm 0.22^{\mathrm{c}}$ & $3.61 \pm 0.01^{\mathrm{bc}}$ & $3.48 \pm 0.01^{\mathrm{ab}}$ & $3.33 \pm 0.05^{\mathrm{ab}}$ & $3.27 \pm 0.02^{\mathrm{a}}$ \\
\hline 6 & Leucine & $5.34 \pm 0.33^{\mathrm{a}}$ & $6.32 \pm 0.01^{\mathrm{c}}$ & $6.01 \pm 0.01^{\mathrm{bc}}$ & $6.41 \pm 0.01^{\mathrm{c}}$ & $5.47 \pm 0.27^{\mathrm{ab}}$ \\
\hline 7 & Phenylalanine & $4.77 \pm 0.22^{\mathrm{c}}$ & $4.09 \pm 0.01^{\mathrm{ab}}$ & $3.91 \pm 0.01^{\mathrm{a}}$ & $4.26 \pm 0.02^{\mathrm{b}}$ & $3.84 \pm 0.03^{\mathrm{a}}$ \\
\hline 8 & Histidine & $3.14 \pm 0.10^{c}$ & $2.24 \pm 0.00^{\mathrm{b}}$ & $2.12 \pm 0.04^{b}$ & $2.19 \pm 0.04^{b}$ & $1.93 \pm 0.01^{\mathrm{a}}$ \\
\hline \multirow[t]{2}{*}{9} & Tryptophan & $0.89 \pm 0.01^{\mathrm{a}}$ & $0.92 \pm 0.00^{\mathrm{b}}$ & $0.89 \pm 0.00^{\mathrm{a}}$ & $0.94 \pm 0.00^{\mathrm{b}}$ & $0.89 \pm 0.00^{\mathrm{a}}$ \\
\hline & Total & $29.52 \pm 1.24$ & $32.14 \pm 0.07$ & $31.87 \pm 0.12$ & $32.10 \pm 0.20$ & $29.38 \pm 0.37$ \\
\hline \multicolumn{7}{|c|}{ Conditionally essential amino acids } \\
\hline 1 & Proline & $4.44 \pm 0.23^{\mathrm{a}}$ & $4.67 \pm 0.01^{\mathrm{a}}$ & $4.48 \pm 0.01^{\mathrm{a}}$ & $4.48 \pm 0.01^{\mathrm{a}}$ & $4.68 \pm 0.01^{\mathrm{a}}$ \\
\hline 2 & Glycine & $4.19 \pm 0.06^{\mathrm{b}}$ & $3.85 \pm 0.01^{\mathrm{a}}$ & $4.81 \pm 0.01^{\mathrm{c}}$ & $3.90 \pm 0.01^{\mathrm{a}}$ & $3.88 \pm 0.01^{\mathrm{a}}$ \\
\hline 3 & Arginine & $4.47 \pm 0.00^{\mathrm{a}}$ & $4.83 \pm 0.01^{b}$ & $4.83 \pm 0.01^{\mathrm{b}}$ & $4.73 \pm 0.01^{\mathrm{b}}$ & $4.45 \pm 0.01^{\mathrm{a}}$ \\
\hline 4 & Cysteine & $1.97 \pm 0.06^{\mathrm{b}}$ & $2.18 \pm 0.00^{\mathrm{c}}$ & $1.74 \pm 0.02^{\mathrm{a}}$ & $2.30 \pm 0.01^{\mathrm{d}}$ & $1.94 \pm 0.01^{\mathrm{b}}$ \\
\hline \multirow[t]{2}{*}{5} & Tyrosine & $3.50 \pm 0.19^{\mathrm{b}}$ & $2.93 \pm 0.01^{\mathrm{a}}$ & $2.62 \pm 0.21^{\mathrm{a}}$ & $2.59 \pm 0.01^{\mathrm{a}}$ & $2.55 \pm 0.04^{\mathrm{a}}$ \\
\hline & Total & $18.57 \pm 0.54$ & $18.46 \pm 0.04$ & $18.48 \pm 0.26$ & $18.00 \pm 0.05$ & $\mathbf{1 7 . 5 0} \pm \mathbf{0 . 0 8}$ \\
\hline \multicolumn{7}{|c|}{ Non-essential amino acids } \\
\hline 1 & Alanine & $5.08 \pm 0.07^{\mathrm{d}}$ & $4.56 \pm 0.01^{\mathrm{c}}$ & $3.87 \pm 0.01^{\mathrm{a}}$ & $4.05 \pm 0.03^{b}$ & $4.03 \pm 0.01^{\mathrm{b}}$ \\
\hline 2 & Aspartic acid & $11.06 \pm 0.88^{\mathrm{a}}$ & $24.13 \pm 0.01^{\mathrm{b}}$ & $25.85 \pm 0.03^{\mathrm{c}}$ & $24.61 \pm 0.01^{\mathrm{bc}}$ & $23.54 \pm 0.35^{\mathrm{b}}$ \\
\hline 3 & Serine & $4.25 \pm 0.04^{\mathrm{b}}$ & $4.38 \pm 0.01^{\mathrm{c}}$ & $4.77 \pm 0.01^{\mathrm{d}}$ & $4.43 \pm 0.00^{\mathrm{c}}$ & $4.11 \pm 0.00^{\mathrm{a}}$ \\
\hline \multirow[t]{2}{*}{4} & Glutamic acid & $15.18 \pm 0.47^{\mathrm{a}}$ & $16.07 \pm 0.02^{\mathrm{b}}$ & $15.63 \pm 0.02^{\mathrm{ab}}$ & $16.05 \pm 0.04^{\mathrm{b}}$ & $15.91 \pm 0.01^{\mathrm{b}}$ \\
\hline & Total & $35.57 \pm 1.46$ & $49.07 \pm 0.05$ & $50.12 \pm 0.07$ & $49.14 \pm 0.08$ & $47.59 \pm 0.37$ \\
\hline
\end{tabular}

*Values in the row are the means of triplicate determinations and those with the same superscript are not significantly different, at $\mathrm{P} \geq 0.05$. 
Table 2. Fatty acid profile of raw and fermented Parkia biglobosa seeds

\begin{tabular}{|c|c|c|c|c|c|c|}
\hline $\mathrm{s} / \mathrm{n}$ & Fatty acids & Raw seeds & $\begin{array}{c}\text { Natural } \\
\text { fermentation }\end{array}$ & $\begin{array}{c}\text { Fermented } \\
\text { with Bacillus } \\
\text { subtilis }\end{array}$ & $\begin{array}{c}\text { Fermented } \\
\text { with } \\
\text { Leuconostoc } \\
\text { mesenteroides }\end{array}$ & $\begin{array}{l}\text { Fermented } \\
\text { with } \\
\text { Lactobacillus } \\
\text { plantarum }\end{array}$ \\
\hline \multicolumn{7}{|c|}{ Saturated fatty acids SFA } \\
\hline 1 & $\begin{array}{l}\text { Caprylic acid } \\
\text { (C8:0) }\end{array}$ & 0 & 0 & 0 & 0 & 0 \\
\hline 2 & $\begin{array}{l}\text { Capric acid } \\
\text { (C10:0) }\end{array}$ & 0 & 0 & 0 & 0 & 0 \\
\hline 3 & $\begin{array}{l}\text { Lauric acid } \\
\text { (C12:0) }\end{array}$ & $0.00 \pm 0.00^{\mathrm{a}}$ & $0.089 \pm 0.00^{\mathrm{c}}$ & $0.167 \pm 0.00^{\mathrm{d}}$ & $0.068 \pm 0.00^{\mathrm{b}}$ & $0.077 \pm 0.00^{\mathrm{c}}$ \\
\hline 4 & $\begin{array}{l}\text { Myristic acid } \\
\text { (C14:0) }\end{array}$ & $0.041 \pm 0.00^{\mathrm{b}}$ & $0.047 \pm 0.00^{\mathrm{c}}$ & $0.892 \pm 0.00^{\mathrm{d}}$ & $0.038 \pm 0.00^{\mathrm{a}}$ & $0.041 \pm 0.00^{\mathrm{b}}$ \\
\hline 5 & $\begin{array}{l}\text { Palmitic acid } \\
\text { (C16:0) }\end{array}$ & $19.403 \pm 0.001^{\mathrm{e}}$ & $16.548 \pm 0.04^{\mathrm{c}}$ & $14.896 \pm 0.06^{\mathrm{b}}$ & $17.7 \pm 0.01^{\mathrm{d}}$ & $14.221 \pm 0.06^{\mathrm{a}}$ \\
\hline 6 & $\begin{array}{l}\text { Margaric acid } \\
(\mathrm{C} 17: 0)\end{array}$ & $0.030 \pm 0.00^{\mathrm{ab}}$ & $0.035 \pm 0.00^{\mathrm{c}}$ & $0.623 \pm 0.00^{\mathrm{d}}$ & $0.028 \pm 0.00^{\mathrm{a}}$ & $0.031 \pm 0.00^{\mathrm{b}}$ \\
\hline 7 & $\begin{array}{l}\text { Stearic acid } \\
(\mathrm{C} 18: 0)\end{array}$ & $11.073 \pm 0.001^{\mathrm{a}}$ & $12.039 \pm 0.01^{\mathrm{c}}$ & $11.649 \pm 0.01^{\mathrm{a}}$ & $12.107 \pm 0.02^{c}$ & $11.888 \pm 0.07^{b}$ \\
\hline 8 & $\begin{array}{l}\text { Lignoceric } \\
\text { acid (C24:0) }\end{array}$ & $0.786 \pm 0.00^{\mathrm{c}}$ & $0.927 \pm 0.02^{\mathrm{d}}$ & $1.14 \pm 0.00^{\mathrm{e}}$ & $0.562 \pm 0.01^{\mathrm{a}}$ & $0.614 \pm 0.00^{\mathrm{b}}$ \\
\hline 9 & $\begin{array}{l}\text { Arachidic acid } \\
\text { (C20:0) }\end{array}$ & $3.256 \pm 0.02^{\mathrm{c}}$ & $3.817 \pm 0.03^{\mathrm{d}}$ & $4.108 \pm 0.01^{\mathrm{e}}$ & $2.261 \pm 0.01^{\mathrm{a}}$ & $2.48 \pm 0.00^{\mathrm{b}}$ \\
\hline 10 & $\begin{array}{l}\text { Behenic acid } \\
\text { (C22:0) }\end{array}$ & $3.240 \pm 0.01^{\mathrm{c}}$ & $3.87 \pm 0.03^{\mathrm{d}}$ & $4.056 \pm 0.02^{\mathrm{e}}$ & $2.192 \pm 0.02^{\mathrm{a}}$ & $2.413 \pm 0.00^{\mathrm{b}}$ \\
\hline & Total & $37.799 \pm 0.03$ & $37.372 \pm 0.13$ & $\mathbf{3 7 . 5 3 1} \pm \mathbf{0 . 1 0}$ & $34.956 \pm 0.07$ & $31.765 \pm 0.13$ \\
\hline \multicolumn{7}{|c|}{ Mono unsaturated fatty acids } \\
\hline 1 & $\begin{array}{l}\text { Oleic acid } \\
(\mathrm{C} 18: 1)\end{array}$ & $20.964 \pm 0.01^{\mathrm{a}}$ & $21.226 \pm 0.01^{\mathrm{b}}$ & $21.884 \pm 0.001^{\mathrm{c}}$ & $24.269 \pm 0.00^{\mathrm{d}}$ & $25.30 \pm 0.05^{\mathrm{e}}$ \\
\hline 2 & $\begin{array}{l}\text { Palmitolenic } \\
\text { acid (C16:1) }\end{array}$ & $0.069 \pm 0.02^{\mathrm{ab}}$ & $0.078 \pm 0.01^{\mathrm{c}}$ & $0.143 \pm 0.01^{\mathrm{d}}$ & $0.062 \pm 0.00^{\mathrm{a}}$ & $0.065 \pm 0.00^{\mathrm{a}}$ \\
\hline & Total & $21.033 \pm 0.03$ & $21.304 \pm 0.02$ & $22.027 \pm 0.01$ & $24.331 \pm 0.00$ & $25.365 \pm 0.05$ \\
\hline \multicolumn{7}{|c|}{ Poly unsaturated fatty acids } \\
\hline 1 & $\begin{array}{l}\text { Linoleic acid } \\
(\mathrm{C} 18: 2)\end{array}$ & $36.074 \pm 0.01^{\mathrm{a}}$ & $39.778 \pm 0.09^{c}$ & $39.422 \pm 0.00^{\mathrm{b}}$ & $39.946 \pm 0.04^{c}$ & $42.099 \pm 0.06^{\mathrm{d}}$ \\
\hline 2 & $\begin{array}{l}\text { Linolenic acid } \\
\text { (C18:3) }\end{array}$ & $0.800 \pm 0.01^{\mathrm{d}}$ & $0.938 \pm 0.01^{\mathrm{e}}$ & $0.717 \pm 0.00^{\mathrm{c}}$ & $0.305 \pm 0.03^{\mathrm{a}}$ & $0.330 \pm 0.00^{\mathrm{b}}$ \\
\hline 3 & $\begin{array}{l}\text { Arachidonic } \\
\text { acid (C20:4) }\end{array}$ & $0.241 \pm 0.00^{\mathrm{b}}$ & $0.283 \pm 0.00^{c}$ & $0.527 \pm 0.01^{\mathrm{d}}$ & $0.221 \pm 0.00^{\mathrm{a}}$ & $0.249 \pm 0.00^{\mathrm{b}}$ \\
\hline \multirow[t]{2}{*}{4} & $\begin{array}{l}\text { Erucic acid } \\
(\mathrm{C} 22: 1)\end{array}$ & $3.393 \pm 0.01^{\mathrm{e}}$ & $0.226 \pm 0.01^{\mathrm{c}}$ & $0.423 \pm 0.01^{\mathrm{d}}$ & $0.178 \pm 0.00^{\mathrm{a}}$ & $0.195 \pm 0.00^{\mathrm{b}}$ \\
\hline & Total & $40.508 \pm 0.03$ & $41.225 \pm 0.11$ & $41.089 \pm 0.02$ & $40.650 \pm 0.07$ & $42.873 \pm 0.06$ \\
\hline
\end{tabular}

*Values in the row are the means of triplicate determinations and those with the same superscript are not significantly different, at $\mathrm{P} \geq 0.05$.

\section{Discussion}

The bacteria load of the fermented sample increased, and this result is in line with what was reported by [4], who reported an increase of $2.01 \log _{10} \mathrm{cfu} / \mathrm{g}$ to $6.63 \log _{10} \mathrm{cfu} / \mathrm{g}$ after the fermentation of Parkia biglobosa seeds. Amao et al. [13] also reported an increase in the microbial load of the Parkia biglobosa seeds fermented with starter cultures of organism. Atere et al. [1] explained that the 
increase in the bacterial load of the fermenting samples during the production of iru from Parkia biglobosa seeds was attributed to the ability of the bacteria involved in the fermentation process to convert the available nutrient in the Parkia biglobosa seeds to produce bacteria biomass which is mainly of protenious nature.

The amino acid composition of the fermented seeds showed an overall improvement in the amino acid content. This observed changes was earlier reported by [14], where fermentation increased the glutamic acid, alanine, aspartic acid and the overall value of the amino acid composition of the fermented sample. Hassan and Umar [15] reported aspartic acid to be $6.87(\mathrm{~g} / 100 \mathrm{~g})$ in the raw seeds of Parkia biglobosa which is different from what was observed in this study. The observed difference in the values may have resulted from the source of the seeds. Glutamic acid was the highest amino acid found in the raw seeds, this is in line with the report of [9]. Fermentation increased the total amino acid content of the sample comparatively, the total values of essential, conditionally essential and non-essential amino acid profile of the raw seeds were lower compared to the seeds fermented naturally and with starter cultures. Ijarotimi and Keshinro [14] attributed the increase to the activity of bacteria used in fermenting the seeds. The bacteria may have converted some of the nutrient in the seeds into amino acids while utilizing the substrate for their metabolism.

The fatty acid profile showed that linoleic acid (C18:2) was highest in the raw seeds as well as the fermented. This result is in line with the previous research carried out on the fermented and raw seeds of Parkia biglobosa [4, 14]. The absence of caprylic acids and capric acids in both the raw and fermented seeds is in line with the report of [4] who reported the absence of the two fatty acids in both raw and fermented seeds. The observed presence of Lauric acid (C12:0) in the fermented seeds of Parkia biglobosa was reported by [3]. The fermentation process increased the linoleic acid (C18:2), a similar trend was observed by [3]. However, [14] reported a decrease in the linoleic acid (C18:2). The difference in this regard may have resulted from environmental factors or the type of organisms involved in the fermentation process.

As earlier reported by other investigators like [3, 16, 17], the high level of linoleic acid and the presence of linolenic acid in a food sample plays an important role in the membrane structure. Linoleic acid and linolenic acid has been regarded as the most important essential fatty acids required for growth, physiological functions and body maintenance [18].

The benefit of the unsaturated fatty acids in diet has been emphasized. It often help in increasing the high density lipoproteins (HDL) often refered to as good cholesterol. Linoleic acid which is the highest fatty acid in the fermented samples has been reported to moderately reduce the serum cholesterol and lowers the low density lipoprotein [3].

The increase in oleic acid and decrease in palmitic acid was also observed in this research as reported by [4]. It was reported that fermentation reduced the palmitic acid and increased oleic acid and this changes may have been a contributing factor to the aroma development in the fermented Parkia biglobosa seeds.

\section{Conclusion}

Conclusively, the sample fermented with Bacillus subtilis is much preferred on the basis of amino acid content. However, on the basis of the fatty acids profile, samples fermented with Lactobacillus plantarum had more unsaturated fatty acid than any other fermented sample. Thus, based on the need of consumers, a starter culture of proven strain can be developed to meet individual need. This research has clearly showed the profile of saturated and unsaturated fatty acids, and the amino acid profile in Parkia biglobosa seeds fermented with different starter cultures. 


\section{References}

[1] Atere, A.V., Oyetayo, V.O. and Akinyosoye, F.A. Effects of starter culture on the Proximate, Antioxidant, Antinutritional and Mineral composition of fermented Parkia biglobosa seeds to produce Iru. International Journal of Food Science and Nutrition 4(4) (2019) 61-65.

[2] Adamu, S.A., Farouq, A.A., Magashi, M.A. and Sokoto, A.M. Studies on fermentation of African Locust beans (Parkia biglobosa L) Journal of Advancement in medical and life science 7(2) (2019)1-3.

[3] Aremu, M.O., Ibrahim, H., Awala, Y.E., Olonisakin, A. and Oko, O.J. Effect of fermentation on fatty acid composition of African locust beans and Mesquite bean. J. Chem. Eng. Res 2(10) (2015) 817-823.

[4] Atere, A.V. and Aderibigbe, E.Y. Studies on the causative factors of odour development during fermentation of Parkia biglobosa. 2nd International Conference and Exhibition (OWSD-FUTA) (2015) 98-103.

[5] Balogun, A.M. and Fetuga, B.L. Chemical composition of some under exploited crops seeds in Nigeria. J. Agric. Food Chem. 34 (1986) 189-192.

[6] Aderibigbe, E.Y., Visessanguan, W., Sumpavapol, P. and Kongtong, K. Sourcing starter cultures for Parkia biglobosa fermentation I: Phylogenic grouping of Bacillus species from commercial 'iru' samples. International Journal for Biotechnology and Molecular Biology Research 2(7) (2011) 121-127.

[7] Odunfa, S. A. Biochemical changes in fermenting African locust bean (Parkia biglobosa) during 'iru' fermentation. Journal of Food Technology 20 (1985) 295-303.

[8] Odunfa, S.A. and Adewuyi, E.Y. Optimization of process conditions for the fermentation of African locust bean (Parkia biglobosa). I. Effect of time, temperature and humidity. Journal of Chemical Technology and Food Microbial 9 (1985) 6 - 10.

[9] Elemo, G.N., Elemo, B.O., Oladunmoye, O.O. and Erukainure, O.L. Comprehensive investigation into the nutritional composition of dehulled and defatted African locust bean seed (Parkia biglobosa). African Journal of Plant Science 5(5) (2011) 291-295.

[10] Brenna, J.T. Efficiency of conversion of alpha-linolenic acid to long chain n-3 fatty acids in man. Curr. Opin. Clin. Nutr 5(2) (2002) 127-132.

[11] Fernandez, M.L. and West, K.L. Mechanisms by which dietary fatty acids modulate plasma lipids. Jor. Nutr. 135 (9) (2005) 2075-2078.

[12] AOAC. Official Methods of Analysis International. 18th Edition. Association of Official Analytical Chemists. USA 2006.

[13] Amao, J.A., Odunfa, F.A. and Mbom, C.N. The role of Staphylococcus species in the production of iru during the fermentation of African locust beans (Parkia biglobosa). Food Research 2(2) (2018): 187-193.

[14] Ijarotimi, O.S. and Keshinro, O.O. Comparison between the amino acid, fatty acid, minerals and Nutritional quality of Raw, Germinated and Fermented African Locust Bean (Parkia biglobosa) flour. Acta. Sci. Pol., Technol. Aliment 11(2) (2012) 151-165.

[15] Hassan, L.G. and Umar, K.J. Protein and amino acid composition of African locust bean (Parkia biglobosa). Tropical and Subtropical Agroecosystem 5:(2005) 45-50

[16] Lynch, D.V. and Thompson, G.A. Re-tailored lipids molecular species: A tactical mechanism for modulating membrane properties. Trends Biochemistry Science 9 (1984) 442-445.

[17] Zuniga, M.E., Lokesh, R. and Kinsella, J.E. Effect of dietary N-6 and N-3 poly unsaturated fatty acids on composition and enzyme activities in liver plasma membrane of mice. Nutritional Research 8 (9) (1990) 1051-1059.

[18] Salunkhe, D.K., Kadam S.S. and Chavan, J.K. Post-Harvest Biotechnology of Food Legumes, CRC Press, Boca Raton, FL (1985)132-140. 